University of Nebraska - Lincoln

DigitalCommons@University of Nebraska - Lincoln

Faculty Publications from the Harold W. Manter Laboratory of Parasitology

$1-1-2005$

Increasing Interest in Parasitology at the Past Three International

Mammalogical Congresses Held in 1997, 2001 and 2005:

Mammals, Parasites, Zoonoses and Biodiversity

\author{
Scott Lyell Gardner \\ University of Nebraska - Lincoln, slg@unl.edu \\ Mitsuhiko Asakawa \\ Rakuno Gakuen University, askam@rakuno.ac.jp \\ Luis A. Ruedas \\ Portland State University, ruedas@pdx.edu \\ Kenichi Takahashi \\ Hokkaido Institute of Public Health, takaken@iph.pref.hokkaido.jp
}

Follow this and additional works at: https://digitalcommons.unl.edu/parasitologyfacpubs

Part of the Parasitology Commons

Gardner, Scott Lyell; Asakawa, Mitsuhiko; Ruedas, Luis A.; and Takahashi, Kenichi, "Increasing Interest in Parasitology at the Past Three International Mammalogical Congresses Held in 1997, 2001 and 2005: Mammals, Parasites, Zoonoses and Biodiversity" (2005). Faculty Publications from the Harold W. Manter Laboratory of Parasitology. 53.

https://digitalcommons.unl.edu/parasitologyfacpubs/53

This Article is brought to you for free and open access by the Parasitology, Harold W. Manter Laboratory of at DigitalCommons@University of Nebraska - Lincoln. It has been accepted for inclusion in Faculty Publications from the Harold W. Manter Laboratory of Parasitology by an authorized administrator of DigitalCommons@University of Nebraska - Lincoln. 


\title{
Increasing interest in parasitology at the past three International Mammalogical Congresses held in 1997, 2001 and 2005: mammals, parasites, zoonoses and biodiversity
}

\author{
Scott L. Gardner ${ }^{1}$, Mitsuhiko Asakawa ${ }^{2, *}$, Luis A. Ruedas ${ }^{3}$ and Kenichi Takahashi ${ }^{4}$ \\ ' Harold W. Manter Laboratory of Parasitology, University of Nebraska - Lincoln, Lincoln, Nebraska 68588-0514, USA \\ ${ }^{2}$ Wild Animal Medical Center, Laboratory of Parasitology (Wildlife Zoology), School of Veterinary Medicine, Rakuno \\ Gakuen University, Ebetsu, Hokkaido 069-8501, Japan \\ ${ }^{3}$ Department of Biology, Portland State University, Portland, Oregon 97207, USA \\ ${ }^{4}$ Department of Biological Science, Hokkaido Institute of Public Health, N-19, W-12, Kita-ku, Sapporo 060-0819, Japan
}

\begin{abstract}
We summarized the data from the past three ITC (now IMC) meetings to examine the potential trends in presentation of parasites of mammals at the meeting. The lists include titles and authors of papers given in symposia, poster sessions, and oral presentations related to diseases, zoonoses, parasites, and causative agents of diseases of sylvatic mammals. Our analysis shows that there has been an increase in the number of papers (from 2.8\% in 1997 to $5.1 \%$ in 2005) presented at the International Mammalogical Meetings. We also show that there are potentially more than 27,000 species of parasites (broadly defined) currently inhabiting the more than 5,400 species of extant mammals. To understand ecological biodiversity, it is necessary to know the complete mammal, including both ecto- and endosymbionts, and the systematics of the mammal itself.
\end{abstract}

Key words: biodiversity, host mammals, International Mammalogical Congresses, parasitology, zoonoses.

At the 9th International Mammalogical Congress (IMC9), among more than 950 delegates representing mammalogy worldwide who presented their work, around 49 papers $(5.15 \%)$ focused on zoonoses, viruses, and parasitism in the classical sense (Table 1).

The themes in the different sessions included, but were not limited to: 1) Emerging zoonoses from mammals, 2) Mammal parasite biodiversity, 3) The epidemiology and management of diseases in wild mammal populations, 4) Macro-ecology of mammalparasite relationships, 5) Carnivores and diseases, 6) Coevolution and cophylogeny of mammals and their micro- and macroparasites.

In this summary, the themes of the research presentation are arranged following the authors' name in alphabetical order under the agent of disease or parasite (e.g., virus, bacteria, protozoans, helminths, arthropods, miscellaneous) (Table 1).

Table 2 represents a summary of papers (symposia, oral, and poster) on parasites of mammals that were presented at the ITC-8 in Sun City, South Africa, 12-17 August, 2001. At this meeting only one session entitled "Mammalian-parasite biodiversity, coevolution, and zoonoses" was dedicated to mammal parasitology. Of the 423 papers presented, only seven $(1.65 \%)$ covered either micro or macro parasites of mammals. The full program and abstracts of oral and poster papers for the ITC-8 can be found at Gardner and Yates (2001). Since there were so few papers on parasites at ITC8, they were not classified by subject area.

Table 3 gives a summary of papers dealing with both micro and macro parasites that were presented at the 7 th International Theriological Congress held in Acapulco, Mexico, September 6-11, 1997. ITC-7 had more than 516 presentors giving either posters or oral talks totaling more than 780 presentations. Of the 780 total, 22 papers $(2.82 \%)$ were given that addressed either macro or micro-parasites of mammals. Only two papers by Felieu 
Table 1. Collected titles of the epidemiology and ecology of wildlife diseases and zoonoses that were presented at the ITC-9.

Authors \& Titles (S: symposia, P: poster sessions, O: oral sessions)

\section{Viruses}

Blasdell, et al. The host range of LCMV and its zoonotic implications (S1006)

Henttonen, H. The emergence of hantaviruses in Europe (S1007)

Henttonen, H. et al. Ecology, occurrence, and dynamics of rodent borne zoonotic viruses in Europe (S1803)

Heroldova, M. et al. Hantavirus infections in Southern Moravia populations of rodents in the years 2000-2004 (P11001)

Hugot, J. P. Hantaviruses in the Muridae: patterns of cospeciation (S1802)

Kallio, E. R. et al. Influence of sex on Puumala virus dynamics in bank vole populations (P27101)

Kida, H. Ecology of influenza viruses in birds and mammals (S1008)

Ruedas, L. Transmission and population dynamics of Hantaviruses in North America (S1809)

Salazar-Bravo, J. Comparative ecology of the rodent hosts of Hantaviruses in the Americas (S1806)

Yoshimatsu, K. et al. Rattus and its close allies as hosts and vectors for viral diseases (S2906)

\section{Bacteria}

Cross, P. C. et al. An overview of bovine TB in African Buffalo in Kruger National Park (\$2303)

Delahay, R. J. et al. Options for the management of bovine tuberculosis transmission from badgers to cattle in the UK (S2301)

Giacometti, M. Infectious keratoconjunctivitis: a multispecies system in Caprinae in the European Alps (S2302)

Haigh, S. Disease management in endangered wild mammal populations of western Australia (S2304)

Hutchings, M. The role of rabbits in the epidemiology of Johne's disease in the UK (S2305)

\section{Protozoa/Protista}

Kawabuchi, T. et al. Babesia microti-like parasites detected in feral raccoons (Procyon lotor) captured in Hokkaido, Japan (PI 1002)

Tsuji, M. et al. Babesia microti-like parasites detected from Eurasian red squirrels (Sciurus vulgaris orientis) in Hokkaido, Japan (P11003)

\section{Helminths}

Azimov, A. D. Biodiversity of nematodes of the family Protostrongylidae parasites of Bovidae (S1811)

Asakawa, M. and Taniyama, H. Perspectives of the hostparasite relationships between the terrestrial mammals and their parasitic nematodes (S1804)

Asakawa, M. et al. Biogeography of the parasitic nematodes of Apodemus speciosus on offshore islands, Japan (S3309)

Chen, H. W. and Dronen, N. O. Geographic distributions and historical ecology of helminth parasites and their Geomys pocket gopher hosts (S1810)

Iwaki, T. et al. A countermeasure to prevent parasitic zoonoses: a baiting trial with anthelmintics against Echinococcus multilocularis in wild red foxes in Japan (S4304)

Kobayashi, T. et al. First record of Trichinella sp. from a feral raccoon (Procyon lotor) in Hokkaido, Japan (P27102)

Kuchboev, A. Structure and function of nematodes of the family Protostrongylidae within a host-parasite system (S1807)

Matoba, Y. et al. Parasitism by helminths in Clethrionomys rufocanus bedfordiae in Nemuro Peninsula, Hokkaido, Japan: influence of age, sex and density of the host (P21801)

Ono, Y. et al. Preliminary report of mammalian helminths in Shiretoko Peninsula, Japan (P27105)

Ruiz, A. J. and Gardner, S. L. Ancestral mammalian hosts for aspidoderid parasites with wide geographic ranges: impact on resulting hypotheses ( $\mathrm{S} 1805)$

Taniyama, H. and Asakawa, M. Epidemiological review of parasitic nematodes obtained from captive mammals in Japanese zoos (P27104)

\section{Arthropods}

Hawlena, H. Agebiased parasitism and density-dependent distribution of fleas on a desert rodent (S4204)

Khokhhlova, I. et al. Immune responses to fleas in rodents in dependence of natural prevalence and diversity of fleas assemblages (P44201)

Krasnov, B. R. et al. Mammalian host determinants of species richness of their ectoparasite assemblages (S4202)

Sashika, M. et al. Severe scabies Sarcoptes scabiei in a feral raccoon (Procyon lotor) in Hokkaido, Japan (P27103)

Shenbrot, G. Relationships between host and parasite geographic range: a case for rodents and Amphipsylla fleas (S4205)

\section{Miscellaneous}

Asakawa, M. et al. Epidemiology and conservation medicine of the carnivore in Hokkaido, Japan (S4302)

Boots, M. Emerging disease: evolution or spillover? (S1002)

Christe, P. Environmental conditions, parasitism, and immune defense in bats (S4203)

Cook, J. A. Beringia: Reflections on a northern biotic interchange (S1808)

Cross, P. C. et al. Duelling timescales of host mixing and disease recovery: a disease perspective of host population structure (S2306)

Gardner, S. L. Phylogenetic systematics, scaling, and the study of coevolution: historical basis and current research (S1801)

Ikeda, T. Control of the invasive raccoon in Hokkaido, Japan: current status and problems to be solved (S1307)

Kanda, E. and Kaneko, Y. Canine distemper and mange in carnivores around Tokyo (S4301)

Matoba, Y. et al. An overview of internal parasites and food habits of feral raccoons (Procyon lotor) in Hokkaido, Japan (S0209 \& W24)

Morand, S. Parasites and mammals: a macro-ecological perspective (S4201)

Nunn, C. L. and Altizer, S. M. Global drivers of parasite diversity and host specificity in primates (S1003)

Perkins, S. E. and Cattadori, l. What's the nature of the species barrier? - A review of emerging zoonotic infections from mammals (S1001) Ryan, S. J. et al. Socially directed disease transmission in primates (S1004)

Solomonov, N. G. and Nikiforov, O. I. Mammals as keepers and carriers of pathogenic organisms causing natural nidi in Yakutia (PI1004)

Telfer, S. et al. Zoonotic microparasite community patterns in a spatially structured host population (S1005)

Yates, T. L. Ecological and evolutionary risk forecasting in zoonotic diseases: the need for synthesis across disciplines (S1812) 
Table 2. Summary of papers on parasites of mammals that were presented at the ITC-8 held in Sun City, South Africa, August 12-17, 2001.

Cowan, P. Parasites for biological control of an introduced mammal pest.

Fischer, C. Sarcoptic mange in foxes: effects of the parastie on activity, spatial behaviour, and feeding habits of the host.

Gardner, S. L. and Yates, T. L. Current state of the science of biodiversity, coevolution, and zoonotic disease research.

Krasnov, B. Host-habitat relations as determinant of spatial distribution of flea assemblages on rodents in the Negev desert.

Miente, G. Intra and inter-specific variation to parasite infection in African mole-rats.

Parkes, J. Impact of rodent haemorrhagic disease on rabbit populations in New Zealand.

Yates, T. L. Climate change and human health: a trophic cascade to hantaviral disease.

Yates, T. L. Summary and synthesis of the symposium.

Table 3. Summary of papers on both micro and macro parasites presented at the ITC-7 held in Acapulco, Mexico, September 6-11, 1997.

Viruses

Henttonen, H., Plyusnin, A., Vapalahti, O., Vaheri, A., Lundkvist, A., Pejcoch, M., Niemimaa, J. and Laakkonen. Hantaviruses in Europe.

Leirs, H. Hunting Ebola virus in Kikwit: lessons for mammalogists.

Mills, J. N., Henttonen, H. Hantaviruses and arenaviruses.

\section{Protozoa/Protista}

Kalema, G. An outbreak of a skin disease in free-ranging mountain gorillas, Gorilla gorilla beringei, in Bwindi Impenetrable National Park, S. W. Uganda.

Laakonen, J. Ecological impact of protozoan and fungal parasitism on small mammal populations.

Ruiz-Pina, H. A., Aban-Cauich, A. S., Rosado-Barrera, M. E., Arjona-Torres, A. D. and Mendoza-Camargo, A. Natural infection by Helminths Trypanosoma cruzi in Didelphis virginiana in Yucatan, Mexico.

Feliu, C., Hugot, J.-P., Renaud, F., Catzeflis, F. and Morand, S. The use of parasitological data to provide a tree of hosts: the case of helminths-rodents in Spain.

Murray, Dennis L. Potential effects of sublethal nematodes on snowshoe hare vulnerability to predation and population dynamics.

Sanabria, M. A., Carmona, A., Martinez, P. J., Chavez-Tapia, C. B. and Lopez, M. F. First ecord in Mexico of Catenotaenia peromysci (Cestoda: Catenotaeniidae) in Peromyscus difficilis (Rodentia: Cricetidae) from Paso de Leon, Hidalgo.

Sanabria, M. A., Osorio, S. D., Espinosa, A. L. L. and Angeles, M. D. First record in Mexico of Trichuris muris (Nematoda: Trichuridae) in Neotoma albigula (Rodentia: Cricetidae) from Paso de Leon, Hidalgo.

Singleton, G., Chambers, L. and Spratt, D. Capillaria hepatica (Nematoda) dynamics in house mice; natural history and field manipulations.

\section{Arthropods}

Anderson, C. and Kok, O. Ectoparasites of the springhare: Pedetes capensis in the northern cape province, South Africa.

Autino, A. G., Claps, G. L. and Barques, R. M. Insectos ectoparasitos de los Murcielagos de las Yungas de la Argentina.

Eckerlin, R. P., Perez, S. G. and McCarthy, T. J. Fleas (Siphonaptera) of small mammals from Sierra de las Minas, Guatemala.

Gannon, M. R. and Patrick, M. J. Ectoparasite associations of bats from Dominica, West Indies.

Krasnov, B. R., Shenbrat, G. I. and Khokhlova, I. S. Flea infracommunities of desert rodents: host specificity versus habitat specificity trade-offs. Coevolution and Miscellaneous

Demastes, J. W., Hafner, M. S. and Spradling, T. A. Coevolution and subterranean rodents.

Gardner, S. L. Collaboration with the Harold W. Manter Laboratory of Parasitology.

Guzman, M. C., Morales-Malacara, J. B., Perez-Ponce de Leon, G., Servin, J. and Lopez-Orteba, G. Preliminary analysis of metazoan parasites of two populations of Tadarida brasilinesis (Chiroptera: Molossidae) in two arid regions of Mexico.

Lochmiller, R. L. Immunocompetence in a variable environment.

Stenseth, N. Should small mammal population ecologists bother about parasites and disease: what are the critical questions?

Vargas, Y. R., Pena Sandoval, G. R., Flores-Estrada, J. J., Chavez-Tapia, C. B. and Taylor, M. L. Frequency of bat fungal infections with Histoplasma capsulatum in caves of the state of Morelos, Mexico.

et al., and Demastes et al., were presented that dealt specifically with coevolution/cophylogeny of mammals and their parasites. The rest (20 papers) were given among three scheduled symposia and distributed throughout the open paper/poster sessions. The full program and abstracts of oral and poster papers for the ITC-7 can be found at Gardner and Yates (2001).

The authors hope that this list will be an useful information for scientists conducting research in parasitology, wildlife disease, and zoonoses. Perhaps this information will serve as a catalyst to enable the creation of a net- work of scientists who are working in this broad field.

\section{Discussion}

Our analysis of trends in the presentation of data on parasites at the International Mammal Meetings shows that more mammalogists are becoming interested in parasites of wild mammals, not only from the view point of zoonoses, but also due to the need to understand the biodiversity of our earth. For example we calculate that the number of species of parasitic organisms outnumber 
free-living species by a factor of at least five to one. This can be arrived at relatively simply: if one species of mammal has at least five host-specific species of parasites (mites, fleas, ticks, protistans/protozoans, nematodes, trematodes, cestodes, or viruses), then for the approximately 5,400 species of mammals described and recognized (Honacki et al. 1982) we would expect a minimum of 27,000 species of parasites to occur in or on extant mammals.

More data on the parasite faunas of mammals must be collected in a rigorous manner for scientists to have a more complete understanding of the parasites of mammals. For us to mount even modest attempts to create conservation corridors or preserve areas of high biodiversity, we must know not only the mammals themselves but also the associates of the mammals. Many times these associates are deeply linked to the ecological areas in which these mammals currently live or evolved, thus showing areas of ancient biological diversity. For instance the presence of a single species of cestode in a small marsupial in the Yungas of Bolivia allowed Gardner and Campbell (1992a, b) to speculate that by using parasites as probes for biodiversity (Gardner and
Campbell 1992a), areas of high and ancient biodiversity can be identified and studied more completely. If the parasites had not been collected during the field work in which mammals were trapped, prepared for museums, and identified and curated, then this data set would be untapped and unknown.

\section{References}

Gardner, S. L. and Campbell, M. L. 1992a. Parasites as probes for biodiversity. Journal of Parasitology 78: 596-600.

Gardner, S. L. and Campbell, M. L. 1992b. A new species of Linstowia Zschokke, 1899 (Cestoda: Anoplocephalidae) from marsupials in Bolivia with comments on the biogeography of cestodes of the genus Linstowia. Journal of Parasitology 78: 795799.

Gardner, S. L. and Yates, T. L. 2001. Mammalian-parasite biodiversity, coevolution, and zoonoses. In: Scientific Program and Abstracts. 8th International Theriological Congress, Sun City, South Africa. 12-17 August, 2001.

Honacki, J. H., Kinman, K. E. and Koeppl, J. W. 1982. Mammal Species of the World: A Taxonomic and Geographic Reference. Allen Press and Association of Systematics Collections, Lawrence, Kansas, USA, 694 pp.

Received 26 November 2005. Accepted 13 January 2006. 